Origins of the European Econom!: Commmications and Conmerce, A.D. 300900. By Michael McCormick. Cambridge \& New York: Cambridge University Press, 2001. xxviii. 1101 pp. $\$ 90.00$ (cloth).

McCormick's massive Origins of the European Economy is a new and significant entry in the debate about the economic side of the transition from antiquity to the Middle Ages, a debate begun long ago by Pirenne and Dopsch and still argued in Pirenne's terms of long distance trade and commerce. McCormick sets out to assess the changing levels and patterns of commerce in early medieval Europe, especially the young Carolingian empire. He seeks, he says. to bring new attitudes. new questions, and new techniques to bear on both old and new evidence. He proposes to approach the commerce of early medieval Europe. so poorly documented. through a study of communications and its infrastructure. since there is much more evidence for these, scattered and sometimes inferential though it is. By bringing together a vast amount of seemingly disparate sources. he hopes first to establish the continuing vigor of Mediterranean communications from the fourth to the ninth centuries, and then to apply his results 10 an evaluation of early Carolingian commerce. In this way he aims to extend recent studies, such as that of Hodges and Whitehouse, which argue against the Pirenne thesis and for an active, expanding economy and welldeveloped networks of local communication and commerce in the seventh, eighth and early ninth centuries in northwestern Europe. ${ }^{1}$ McCormick's astute analysis of the evidence does indeed create a convincing picture of Mediterranean communications in the early Carolingian era: the extension of the analysis to commerce. however. is less persuasive.

McCormick develops his argument in logical sequence. First, he establishes the state of the Mediterranean economy in late antiquity, with an emphasis on slipping and industry and their supporting systems. Next is a detailed study of Mediterranean travelers-diplomats. pilgrims, and othersheaded both eastward and westward, most from the eighth and ninth centuries. He has gathered records of such people in sufficient numbers to permit grouping and simple numurical comparisons. Moving objects, as opposed to people, are traced through the collections of eastern relics in two western shrines and through hoards of Arab and Byzantine coins found in northern and western Europe. Next, he analyses travel itself: the routes over land and sea; the ships and other transport: the speed achieved: the effects of weather, season. and changes in technology and political boundaries. The last major section is devoted to

\footnotetext{
' Richard Hodges and David Whitehouse, Mohammed, Charlemagne \& she Origins of Europe: Archaeology and the Pirenne Thesis (Ithaca NY: Comell University Press, 1983): see also Joln Haywood. Dark Age Naval Power: a Reassessment of Frankish and AngloSaxon Seafaring Acrivin' (New York: Routledge, 1991).
} 
Carolingian commerce. with discussions of regional networks of trade and their links to each other followed by discussions of imports and exports and of what things were desired or available for purchase. Here. viewing Europeans as consumers, he considers the effects of changing tastes on the demand for such commodities as spices and papyrus.

Throughout his book. McCormick scrutinizes information from a wide range of sources (from hagiography to coin hoards) with a variety of techniques (from literary analysis to simple tabulations). His work has the breadth of a survey in the topics it addresses but a narrowness of focus and argument sustained by constant close engagement with the evidence. The extensive bibliography (eighteen pages of primary sources and fifty-six pages of secondary literature) reveals the broad range of materials he has drawn on for the multitudinous details, often condensed into tables and lists that fill the work. The size and specific contents of the bibliography are significant: they give a clear indication of McCormick's effort to carry out a truly comprehensive study, and reflect his attempt to create so large a database that groups within it acquire statistical significance. He speaks. too, of the use of computers and notes their ability to find every mention of a single word-such as 'merchant - in lengthy documents.

There are. of course, the usual problems of quantitative history. The data are not a random selection; they are whatever was then thouglit worth recording and which has happened to survive. Commerce in the sense of direct buying and selling was of little interest to those whose writings form the majority of available sources. McCormick discusses the lack of mention of merchants and markets in surviving documents: too many of these documents (from an economic historian's viewpoint) come from the records and arclives of ecclesiastics, whose chief concems were otherworldly. Passing mentions may imply an established. taken-for-granted market system. but they contribute little to the specific. quantifiable data sought by McCormick. " Nevertheless. McCormick has enough evidence that he can discuss categories of travelers-old. young. healthy, feeble, male, female. officials. pilgrims. He extracts data from every conceivable source and arranges it in tabular form or in lists. displayed in a sizable appendix of travelers and joumeys: these include all those known for the seventh and eighth centuries. in chronological order. and the maps of western hoards of eastern coins. both Arabic and Byzantine.

The chapters dealing with travel and travelers are interesting and wortly of study in and of themselves, quite apart from their place in McCornick"s

\footnotetext{
${ }^{2}$ A few accidental letter deposits. such as those at Vindolanda. Bergen and Novgorod. offer tantalizing hints of what was going on outside the archive-minded monasteries. See. for instance. Mary Garrison. "Send More Socks: on Mentality and the Preservation Context of Medieval Letters." New Approaches to Medieval Communication. ed. Marco Mostert (Tumhout: Brepols. 1999), 69-99.
} 
argument about Carolingian commerce. For instance, a section about Mediterranean sailing includes a discussion of the resurgence of night sailing. increasingly adopted in the ninth century, which not only more than doubled the actual distance covered in a day, but also increased the ship's effective range, since it no longer needed to cling to the coast and was thus able to take more direct routes. Much of interest to historians other than those involved in the Pirenne debate about early medieval trade can be found gathered and analyzed here-just as McCormick himself finds his information and inspirations in documents and objects collected for purposes very different from his own.

McConnick's argument about commerce is largely indirect. He expends much effort in showing the extent of movement and communication because of its implications for commerce, his ultimate concern. His argument consists to some extent of a piling up of evidence, whether from independent sources such as relic collections and coin hoards or from the records of individual travelers, and augmented by all the inferences to be drawn from those bits of evidence. Certainly. as he points oul, movement of one person or object from one end of the Mediterranean to the other necessarily involves the movements of many other people and objects. The problem. which McCormick acknowledges, is that movement. even of objects. cannot be directly equated with commerce. Grierson's analysis of the ways in which early medieval goods changed hands is now almost lifty years old. but his assertion that buying and selling played a minor role in the movement of goods still keeps historians wary in their assumptions about early medieval commerce. ${ }^{3}$

One instance in which movement does come close to commerce, however. is the case of slavery. The slaves who were captured in pirate raids or seized by war bands and taken out of Europe were all objects of commerce, bound for the slave markets of North Africa and the eastern Mediterranean. McCormick pursues the traces of slaves in hagiography and in sources related to the rise of Venice: he documents these unfortunates as thoroughly as scattered references allow. It is the records of these slaves (and it is perhaps worth noting that they represent exports, not the imports that earlier studies have focused on), which bring us closest to unmistakable commerce.

Thus the old argument. becoming weaker of late, that commerce declined because the arrival of the Arabs closed the Mediterranean to Christian travel is further reduced by McCormick's demonstration of continuous travel. McCormick shows. in detail and convincingly, that the amount of movement recorded and the infrastructure that supported it constitutes a great deal more activity than historians used to think occurred. and imply more still. His picture

\footnotetext{
'Philip Grierson. "Commerce in the dark ages: a critique of the evidence," Transactions of the Roual Historical Socien. 5:9 (1959): 123-140.
} 
of roads and seas filled with purposeful travelers and their goods works well for establishing the continuous existence of long distance movement: indeed. as McCormick notes, the constant opening of new routes to replace those shut down by adverse political conditions itself argues for continuing pressure from travelers. This aspect of McCormick's work is wholly successful. and it. along with his collection of sources and data. will be valuable for years to come. McCormick is less successful, however, in his attempt to establish the full economic import of that movement and its commercial sector in particular: the links between movement and commerce, plausible though they may be. are not conclusively demonstrated. Much work remains to be done here. in a field now enriched by the scope and liveliness of McCormick's book.

\section{Pat Ditchak}

Universin of Alberta

Solitany Sex: A Cultural Histony of Masturbation. By Thomas W. Laqueur. New York: Zone Books, 2003. 501 pp. $\$ 34.00$ (cloth).

With his newest book Solitary Sex: A Cultural History of Masturbation. Thomas Laqueur has once again undertaken a massive research project relating to the human body and the changing ways people relate to it. As with his earlier work. Making Ser: The Body and Gender from the Greeks to Freud (1990). this book is bound to stimulate a great deal of discussion in academic circles. While focusing upon the modern era. it nonetheless does attempt to provide an overview of Westem attitudes towvard masturbation during the past two-and-a-half thousand years. In order to do so, Laqueur has consulted a vast array of sources. from philosophical writings to medical treatises. from religious texts to bawdy epigrams, from personal correspondence to sites on the worldwide web. However, impressive as Laqueur's research is, it is to be expected that such a vast undertaking can do little more than scratch the surface of the subject. and this makes the author's argument susceptible to criticism.

In this book, Lacquer puts forward the thesis that the notion of masturbation-as-vice, a western European phenomenon. was invented in or around the year 1712 with the publication of a booklet entitled "Onania." According to Lacquer, masturbation was designated an evil activity because it showed the dangerous extremes to which the qualities and characteristics of modern life espoused by Enlightenment thinkers could be taken. In the case of masturbation. privacy was used for self-gratificalion and not for the public good. Imagination. as well. was employed for self-gain. rather than being used to promote social cohesion and proper conduct. Silent reading also began to flourish at about this time as well, and concern with this practice arose for some 